Miloš Vorkapić ${ }^{1}$
Dragan Ćoćkalo $^{2}$
Dragana Sajfert $^{3}$
Dejan Đorđević $^{4}$
Strahinja Cvijanović
JEL: C44, L23, Q01

DOI:10.5937/industrija45-10089

UDC: $658.51(497.11)$

005.591.1:334.713

Original Scientific Paper

\title{
The model for improving the manufacturing process in Serbian small-scale production enterprises $^{6}$
}

\author{
Article history: \\ Received: 25 January 2016 \\ Sent for revision: 17 February 2016 \\ Received in revised form: 3 February 2017 \\ Accepted: 3 February 2017 \\ Available online:5 April 2017
}

\begin{abstract}
The paper presents a theoretic model for improving the manufacturing proces that was developed and tested in small-scale production enterprises. The model also represents a new organizational model which enables a complete implementation of pull strategy, insufficiently used in Serbia up to now, with a stress on sustainable manufacturing process, remanufacturing process and environmental protection. The model also includes the guidelines to SMEs - how to use energy, materials and water rationally during the process of manufacturing new products. Development of new products in SMEs on the territory of the Republic of Serbia is burdened by numerous problems among which the most influential ones are: financial flow, poor market estimation, lack of knowledge, lack of ISO 9001 certificate and weak organizational structure. On the bases of the data research we have identified the following problems in small enterprises: individual knowledge, distribution and realization of work tasks, increase of operational expenses caused by bad distribution of work tasks, exceptionally poor communication with consumers.
\end{abstract}

\footnotetext{
${ }^{1}$ University of Belgrade, Institute of Chemistry, Technology and Metallurgy (ICTM) Center of Microelectronic Technologies, Belgrade, Serbia, worcky@nanosys.intm.bg.ac.rs

${ }^{2}$ University of Novi Sad, Technical faculty "Mihajlo Pupin" in Zrenjanin, Serbia

${ }^{3}$ University of Novi Sad, Technical faculty "Mihajlo Pupin" in Zrenjanin, Serbia

4 University of Novi Sad, Technical faculty "Mihajlo Pupin" in Zrenjanin, Serbia

${ }^{5}$ Centum d.o.o., Belgrede, Serbia

6 This paper is the result of a project supported by the Serbian Ministry of Education and Science, Grant TR 35017.
} 
Vorkapić M. et al.: The model for improving the manufacturing process in Serbian...

Keywords: Small-scale production, Manufacturing process, Sustainable development, Remanufacturing, Cybernetic model, Serbia.

\section{Model za unapređenje procesa proizvodnje u srpskim preduzećima sa maloserijskim tipom proizvodnje}

Apstrakt: U radu je prikazan teoretski model za poboljšanje procesa proizvodnje koji je razvijen $i$ testiran u malim proizvodnim preduzećima. Takođe, model predstavlja nov organizacioni model koji omogućava potpunu primenu pull strategije koje nije dovoljno zastupljena u Srbiji, a sa osvrtom na održivi proces proizvodnje proces ponovne proizvodnje, i sve zastupljeniji aspekt zaštite životne sredine. U modelu su dete smernice o tome kako da SMEs racionalno troše energiju, materijale, vodu $i$ enrgiju $u$ procesu proizvodnje novog proizvoda. Razvoj novih proizvoda u SMEs na teritoriji Republike Srbije prate mnogi problemi, a među najuticajnijim su: finansijski tokovi, Ioša procena tržišta, znanje nedostatak ISO 9001 sertifikata i slaba organizaciona struktura. Na osnovu podataka iz istraživanja, identifikovani su sledeći problemi u malim preduzećima: znanja pojedinaca, distribucija $i$ realizacija poslovnih zadataka, porast operativnih troškova zbog loše podele poslova, izrazito loše komunikacije sa potrošačima.

Ključnereči: Maloserijska proizvodnja, Proizvodni proces, Održivi razvoj, Reproizvodnja, Kibernetki model, Srbija.

\section{Introduction}

According to an EU classification, firms with fewer than 50 employees are small enterprises (SE), while those with fewer than 10 workers are considered to be micro enterprises (ME) (Lindner and Bagherzadeh, 2005). Urošević and Stamatović (2011) report that small and micro enterprises (SME) in Serbia represent $99.8 \%$ of the total number of enterprises, $65.5 \%$ of employment, $67.6 \%$ of turnover, and about $36 \%$ of gross domestic product. Micro enterprises dominate in the SME segment with $93.5 \%$ share (Djordjevic et al., 2011).

SMEs generally implement closed strategies for new product development. The major risk of such strategies is inability to identify and pursue any business opportunity outside the present product scope (Tapio Lindman, 2002). Successful new product development requires strong interactions with customers through sales, marketing and product design activities in order to clearly understand changes in customer needs (Handfield et al., 1999). In addition, SMEs in more developed economies often integrate suppliers in the new product development through joint education and training activities, 
Vorkapić M. et al.: The model for improving the manufacturing process in Serbian...

feasibility studies, set up of common performance goals and product design assessment (Petersen et al., 2003).

Over the last 25 years Serbian economy has suffered enormously as a result of violent disintegration of Yugoslavia and inefficient privatization during early stages of transition, which had major effects on the local SME operations and practices. The research describing new product development in Serbian SMEs has not been much covered in literature. Just a few references can be found, but their focus is on new product development in high-tech SMEs which covers a minor fraction of manufacturing enterprises in Serbia (Bošković, 2011).

This paper will present our research on the development of a new manufacturing process organizational model whose aim is to improve business performance of SMEs on the territory of Serbia. The paper includes a discussion on the main problems concerning new product development and the recommendations for improving the manufacturing process as well.

\section{Research methodology}

The research was conducted in order to establish a theoretical model which would improve production processes in enterprises with small-scale type production in Serbia. Thus, the research questions were formulated as follows:

RQ1: On the basis of the previous analysis of the current situation in smallscale enterprises in Serbia, it is possible to establish a theoretical model for improving production of small-scale type enterprise which integrates quality control and remanufacturing?

RQ2: Can small-scale enterprises in Serbia recognise the benefits of possible implementation of this model?

The model encompassed: the process of managing the manufacturing process (the product realization process), an analysis of production and nonproduction time, the resource management process, the managing waste materials process, the environmental management process, and an analysis of the process and implementation of activities aimed at improving the manufacturing process. The model was subjected to a specific reality test to check its eligibility for small-scale enterprises in Serbia.

\subsection{The research hypothesis}

It is possible to construct a theoretical model in enterprises with small-scale production (SP) in Serbia which integrates the demands involved in the quality 
Vorkapić M. et al.: The model for improving the manufacturing process in Serbian...

management of development, production and new product launch processes, the requirements related to reducing stoppages in those processes and the demands of sustainable production along with decreasing the costs of producing a new product.

\subsection{Target groups}

This research covered 76 small manufacturing enterprises including 48 MEs and 28 SEs. The questionnaires were completed by managers, their deputies, or other company representatives. As Table 3 shows, the research sample included primarily low-and medium-tech enterprises representing a broad range of businesses.

Table 1 Manufacturing enterprises in Serbia covered by this research

\begin{tabular}{lc}
\multicolumn{1}{c}{ Business area } & $\begin{array}{c}\text { Number of } \\
\text { respondents }\end{array}$ \\
\hline $\begin{array}{l}\text { The production of machines and devices, The production of } \\
\text { electric and fiber devices }\end{array}$ & 16 \\
$\begin{array}{l}\text { The production of chemicals, chemical products and } \\
\text { artificial and synthetic fibers }\end{array}$ & 16 \\
The production of rubber products and products made from & 14 \\
plastic mass & 12 \\
The production of basic metals and standard metal products & 8 \\
Wood processing and products made from wood & 2 \\
The production of food products & 2 \\
The production of textiles and textile products & 2 \\
The production of leather and objects made from leather & 2 \\
Publishing and printing & \\
\hline
\end{tabular}

The results were initially analyzed using descriptive statistics. The Chi-Square test was also used to investigate if new product development practices in MEs compared to SEs are different. The value of $p<0.05$ was taken to indicate statistical significance for rejecting the null hypothesis of homogeneity between ME and SE categories. The Chi-Square test was used to analyse the correlation level between the elements of the production process, and Spearman'stest for the analysis of production and non-production time in the production process. The value of $p<0.05$ was taken to indicate statistical significance, i.e. it indicates that there is a functional correlation between the analysed elements. 
Vorkapić M. et al.: The model for improving the manufacturing process in Serbian...

\section{Theoretical model}

The model (hereinafter MIMP-SPE) was created in accordance with the available literature sources which deal with the same or similar issues (Hallberg, 2000; Maxwell \& van der Vorst, 2003).

This theoretical model, see Figure 1 , is in indirect correlation with those reviews which treat SP as the acceptable one, clean and sustainable direction of industrial development, or some branches of industry, especially in the segment of small (and medium) enterprises, (Desai, 2008; Sandee \& Rietveld, 2001; Subrahmanya, 2005).

Figure 1 Schematic presentation of the MIMP-SPE model

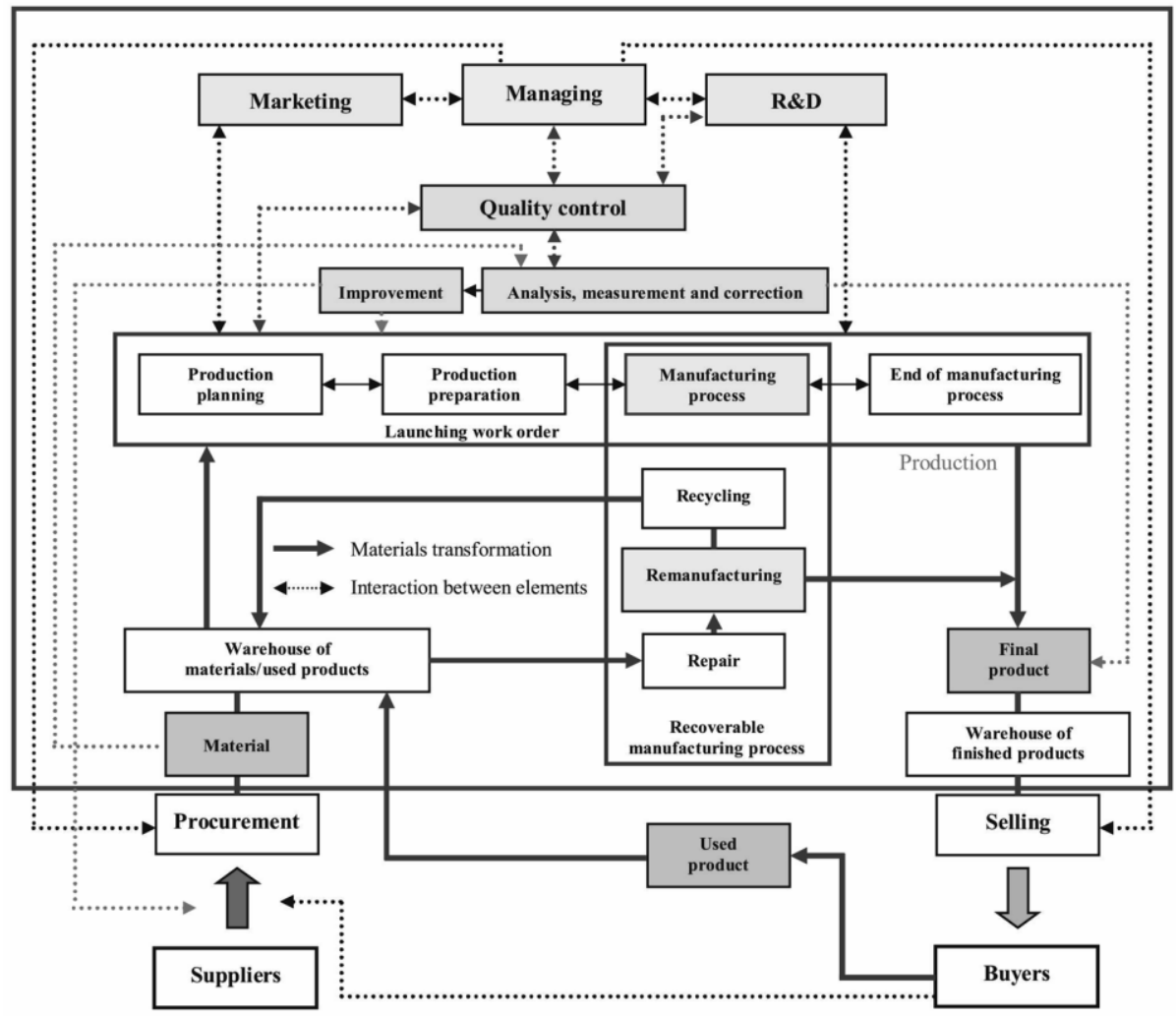

ENVIRONMENT 
Vorkapić M. et al.: The model for improving the manufacturing process in Serbian...

According to Figure 1, the production process usually (Buffa, 1983) consists of four sub-processes: production planning, production preparation, the manufacturing process and the end of the manufacturing process.

The MIMP-SPE model takes into consideration the stochastic model of establishing the production cycle time, (Čala, Klarin, \& Radojčić, 2011). Measuring the production cycle includes the period from the moment of the input of raw material (or material) in the first operation of the manufacturing process until the output of the finished product, i.e. the period is divided in two stages: production and non-production, (Klarin et al., 2012).

The production process is defined as a transformation process of input into output units. Many authors (Anderson, 1987; Mallidi, Paraskevopoulos, \& Paganelli, 1999) define three main types of input: materials, energy and other factors. In this regard, the aforementioned literature sources also indicate other factors, which include: water, tools, operating supplies and information. The output units in the transformation process are usually: the finished product, material loss, loss of energy and time losses.

\subsection{Production}

Production planning includes the following planning activities: product development, technology development, the use of labour, space and resources for work.

Product development should provide the enterprise with the capability to identify new product possibilities and to develop an organizational model for the realization of a new product, (Abrahamson, Wallace, Senin, \& Sferro, 2000).

Space planning involves the layout of working tools and auxiliary space. At the end, the Planning of working resources includes: the need for working resources, acquisition of such resources, revitalisation of existing resources and tools, and their maintenance and engagement pursuant to the production plan.

Production preparation consists of the following elements: operational planning, scheduling, initiating the production process (launch of work orders), monitoring and coordinating all activities in the process.

This model points at the importance of the meanig of launching. A work order is launched first (see Figure 1). It should include the number, the name and amount of a product, the beginning and end of the manufacturing process as well as the verification of technical control of the product.

The manufacturing process in the MIMP-SPE model points out the importance of the following elements: nature and type of job, internal transport, storage, 
Vorkapić M. et al.: The model for improving the manufacturing process in Serbian...

protection and safety measures, preventive maintenance of working tools, and supplying the process with water and energy.

The enterprise needs to guarantee regular health checkups in accordance with the risks at work (Arocena \& Núñez, 2010; Cagno, Micheli, Jacinto, \& Masi, 2014).

At the end of the manufacturing process, an analysis of all the parameters of the production process must be carried out, as well as any eventual product servicing.

\subsection{Managing production elements}

Successful management of small-scale manufacturing process in domestic enterprises includes the involvement of management in activities optimization and reduction of input costs, measuring manufacturing and nonmanufacturing time in the product production cycle.

Properly chosen staff, i.e. their quality dictates the survival and development of the enterprise, (Kerr \& McDougall, 1999). Unlike SEs, large enterprises have the possibility to "take" the most qualified employees from the labor market and keep them for themselves, because SEs are often unable to offer adequate salaries for qualified experts, (Milovanović, 2005).

The need for human resources includes a sequence of activities in which the number of employees with their knowledge, skills and capabilities is defined, (Bohlander \& Snell, 2010).Roper (1998) and Camuffo, Gerli, and Gubitta (2012)propose the qualities a SE manager must possess: self-control, the ability to gather information, vision, planning and business negotiation skills and organization awareness.

\subsection{Research and Development}

Today, the term product life cycle includes: faster product development (Ali, Krapfel, \& LaBahn, 1995; Griffin, 1997), disassembling the product, repair and reuse of parts and components (Westkàmper, Feldmann, Reinhart, \& Seliger, 1999).R\&D in production tests, the possibility of conquering new markets, make a production plan, make TK documentation, and define the manufacturing program and the organization of labor (see Figure 1).

\subsection{Qulity control}

The function of self-control is very important during the manufacturing process. It is enforced by a worker personally through the control of parts and assemblies until the final control of a finished product. Managing production 
Vorkapić M. et al.: The model for improving the manufacturing process in Serbian...

elements is done through quality control which includes: 1) the analysis, measurement and correction of output parameters and 2) the improvement of input parameters (see Figure 1).

\subsection{Environment}

Esteve-Pérez and Rodríguez (2013)showed that there is a strong connection between properly chosen technology and environmental factors on the development of new products.Many authors (Borland \& Wallace, 1999; Jeffrey \& Hunt, 1985), point out that product design includes: the procurement of components for production, assembling, service, obsolescence, energy efficiency, the possibility of recycling and avoidance of using toxic matter. In this regard, Hauschild, Jeswiet, and Alting (2004) indicate that in the production process the attention should be paid to the organization through: reducing the consumption of energy and resources, reducing the use of toxic materials; the use of good quality materials, as well as the possibility to upgrade, repair and recycle products.

The MIMP-SPE model also takes into (see Figure 1) account waste prevention techniques summarized as the so-called 4Rs model or the Canadian model ("The 4Rs - reduction, reuse, recycling and recovery," 2013) which includes: 1. Reduction; 2. Reuse; 3. Recycling and 4. Recovery. The model incorporates elements of systems analysis on the remanufacturing and manufacturing relationship. According to Konstantaras and Skouri (2010), a system is considered satisfactory if there is a demand for manufacturing and remanufacturing. This system involves the purchase of products from the buyer, their storage and later use in the remanufacturing process.

\section{Analysis of the research results}

\subsection{Production}

On the grounds of the processed data it was concluded that the development of new products in small - scale production was mainly realized through modification 50 (62.5\%).According to the answers, modification represents successively: use of the current capacity 38 (47.5\%), avoiding big investment in the research and development of products $36(45 \%)$ as well as small modifications of the product $34(42.5 \%)$. To conclude, the reasons for investing in the new product are directly connected to: improving enterprise's competitiveness 60 (75\%) and distinguishing product quality 36 (45\%).

According to the data, a manufacturing process begins with delivering a work order 66 (82.5\%). Workshop drawings are not used enough 38 (47.5\%). 
Vorkapić M. et al.: The model for improving the manufacturing process in Serbian...

Operational preparation of the manufacturing process and time work norm are significant in relation to the type of work/task and preventive maintenance (see Table 2).

Table 2. The significance of operational preparation of production and timely work norms

\begin{tabular}{|l|c|c|}
\hline \multirow{2}{*}{ Activities } & \multicolumn{2}{|c|}{$\mathbf{x}^{2}$} \\
\cline { 2 - 3 } & $\begin{array}{c}\text { Type of } \\
\text { job/task [p] }\end{array}$ & $\begin{array}{c}\text { Preventive } \\
\text { maintenance [p] }\end{array}$ \\
\hline Operational preparation of production & 0.027 & 0.009 \\
\hline Timely work norms & 0.015 & 0.023 \\
\hline
\end{tabular}

Based on the received responses proper distribution of employees is present in some cases $54(67.5 \%)$ while the training is carried out at work place 76 $(95 \%)$. Workers are assigned from one to three work activities during the day $52(65 \%)$.

Machine distribution is mixed $56(70 \%)$ and there is a relatively high disharmony in their work during the manufacturing process $46(57.5 \%)$. Internal transport is characterized by stoppages $48(60 \%)$.

In SP all of the required protection measures in the work place are applied 72 $(90 \%)$, general warning and safety signs are displayed $66(82,5 \%)$, there are guidelines for risk degree and safety in the work place $56(70 \%)$, as well as preventive medical protection $48(60 \%)$.

Preventive maintenance in small-scale enterprises is mostly focused on: regular inspections $46(57.5 \%)$ and to a lesser extent on part replacement 22 (27.5\%).

Water is mostly used in the production system $52(65 \%)$ and from a public water supply $64(85 \%)$. SEs are powered by electrical energy directly from the power grid 76 (95\%).

According to the analysed results, over half of the respondents respect the chronological order of technological operations $48(60 \%)$. Input, intermediate and output records are controlled as required 46 (57.5\%), which is a poor indicator of the production process.

The analysis of production and non-production time was carried out in a small scale enterprise (ICTM-CMT, Belgrade) which manufactures pressure and temperature sensors. 30 recordings were made related to issued work orders, and the goal was to determine the degree of working time spent on certain jobs/tasks. The results point out the problems concerning certain jobs/tasks.

Table 3 presents the correlations between manufacturing and nonmanufacturing time for which purpose a Spearman test was used. Based on 
Vorkapić M. et al.: The model for improving the manufacturing process in Serbian...

the results, it can be seen that with the increase of preparation-finishing time $\left(t_{p f}\right)$ manufacturing time decreases $\left(t_{t m}, p=0.032\right)$, product packaging time decreases $\left(t_{p k}, p=0\right)$, and delays due to lack of materials $\left(t_{p k}, p=0\right)$ and other factors $\left(t_{o t}, p=0.042\right)$ are also reduced. The increase in manufacturing time for product elements results in a fall in both transport time $\left(t_{t r}, p=0.016\right)$ and product packaging time $\left(t_{p k}, p=0.023\right)$. With the increase of control time $\left(t_{t c}\right)$, packaging time also increases $(p=0.017)$ and delays occur due to other factors $(p=0)$. The increase in transport time leads to a reduction in delays related to tools $\left(t_{t}, p=0.005\right)$, while the increase in packaging time cuts delays due to other factors $(p=0.037)$

Problems which occur during the improvement of the manufacturing process, according to the level of significance, are given respectively: jobs mismatch $36(45 \%)$, large operational expenses $26(32.5 \%)$ and the repetition of certain operations $16(20 \%)$. Problems which occur on the organizational level are related to the division and realization of tasks 54 (67.5\%). According to the opinions of the respondents, according to the level of significance, the most influential weakening factors of a small-scale enterprise are given respectively: deferred payments 30 (37.5\%), financial flows $28(35 \%)$ and individual knowledge 28 (35\%).

Table 3.Correlations between manufacturing and non-manufacturing time in the model

\begin{tabular}{|c|c|c|c|c|c|c|c|c|c|c|}
\hline \multirow{2}{*}{ Time } & \multicolumn{5}{|c|}{ Manufacturing time $t_{\mathrm{p}}$} & \multicolumn{5}{|c|}{ Non-manufacturing time $t_{\mathrm{hp}}$} \\
\hline & $t_{p t}$ & $t_{m m}$ & $t_{0}$ & $t_{r}$ & $t_{p k}$ & $\mathbf{t}_{\mathrm{mr}}$ & $t_{1}$ & $t_{0}$ & $t_{b}$ & $t_{\text {ot }}$ \\
\hline$t_{p t}$ & 1.000 & 0.352 & $-0.393^{\circ}$ & -0.289 & $-0.624 \ddagger$ & $-0.615 \ddagger$ & 0.340 & -0.057 & -0.214 & $0.374^{\circ}$ \\
\hline $\mathrm{t}_{\mathrm{m}}$ & 0.352 & 1.000 & -0.030 & -0.437 & $-0.415^{\circ}$ & -0.335 & 0.150 & -0.045 & -0.158 & -0.212 \\
\hline$t_{c}$ & $-0.393^{\circ}$ & -0.030 & 1.000 & 0.100 & $0.432^{\circ}$ & -0.061 & -0.188 & -0.084 & -0.291 & $-0.616 \ddagger$ \\
\hline$t_{r}$ & -0.289 & $-0.437^{\circ}$ & 0.100 & 1.000 & 0.183 & -0.020 & $-0.497 \ddagger$ & 0.244 & 0.162 & -0.322 \\
\hline$t_{\mathrm{pk}}$ & $-0.624 \ddagger$ & $-0.415^{\circ}$ & $0.432^{\circ}$ & 0.183 & 1.000 & 0.169 & 0.038 & -0.185 & 0.214 & $-0.382^{\circ}$ \\
\hline$t_{m r}$ & $-0.615 \ddagger$ & -0.335 & -0.061 & -0.020 & 0.169 & 1.000 & -0.141 & 0.194 & 0.134 & -0.147 \\
\hline$t_{1}$ & 0.340 & 0.150 & -0.188 & $-0.497 \ddagger$ & 0.038 & -0.141 & 1.000 & -0.332 & -0.189 & 0.152 \\
\hline$t_{0}$ & -0.057 & -0.045 & -0.084 & 0.244 & -0.185 & 0.194 & -0.332 & 1.000 & 0.000 & -0.268 \\
\hline$t_{0}$ & -0.214 & -0.158 & -0.291 & 0.162 & 0.214 & 0.134 & -0.189 & 0.000 & 1.000 & 0.096 \\
\hline$t_{\text {ot }}$ & $0.374^{\circ}$ & -0.212 & $-0.616 \ddagger$ & -0.322 & $-0.382^{\circ}$ & -0.147 & 0.152 & -0.268 & 0.096 & 1.000 \\
\hline
\end{tabular}

${ }^{*} p<0.05 ; \ddagger p<0.01$ 
Vorkapić M. et al.: The model for improving the manufacturing process in Serbian...

\subsection{Managing production elements}

The research results have showed that managers need to possess knowledge from the field of Technological Science and Humanities 74 (92.5\%). Good interpersonal relations are also important for creating a favourable ambience $62(77.5 \%)$. During the research majority of respondents have improved their skills in the field of quality $46(57.5 \%)$ and new technologies $24(30 \%)$.

\subsection{Research and Development}

The ideas for product development mostly come from buyers $50(62.5 \%)$, competitors $50(62.5 \%)$, and fairs and exhibits $48(60 \%)$. SEs from Serbia occasionally carry out research activities $56(70 \%)$, develop technological solutions for making new products $48(60 \%)$.

\subsection{Quality Control}

Self-control procedures are enforced in the work place 76 (95\%). Regular control of measuring tools and measuring instruments is carried out: regularly $38(47.5 \%)$ and when required $32(40 \%)$. The input control of the quantity of delivered material $66(82.5 \%)$ and the final control of the finished product 62 $(77.5 \%)$ is carried out in warehouses.

\subsection{Environment}

For the respondents, according to the level of significance, the competitive advantage of the company reflects on: product quality $74(92.5 \%)$, the price of the product $70(87.5 \%)$ and product design $36(45 \%)$. Environmental dangers that influence an enterprisels business activities are: market instability 40 $(50 \%)$, short delivery deadlines $32(40 \%)$, and supplier risk $30(32.5 \%)$.

To penetrate and succeed on the market SEs have to apply numerous strategies. The functional relationships between strategies and MIMP-SPE model elements are shown in Table 4. The strategy for increasing production volume depends on: product modification $(p=0)$, warehouse use $(p=0.05)$, distribution of workers according to their qualifications $(p<0.05)$, and maintenance service $(p<0.05)$. In the strategy for attracting new markets, SEs mostly create products according to specifications and documentation sent by a buyer $(p<0.005)$. 
Vorkapić M. et al.: The model for improving the manufacturing process in Serbian...

Table 4 Relationships between strategies and enterprise elements in the MIMP-SPE model

\begin{tabular}{|l|c|c|}
\hline \multirow{2}{*}{ Strategy for increasing production volume } & \multicolumn{2}{c|}{$\mathbf{X}^{2}$} \\
\cline { 2 - 3 } & Respondents & $\mathbf{p}$ \\
\hline Product modification & $18(45 \%)$ & 0 \\
\hline Warehouse use & $24(60 \%)$ & 0.05 \\
\hline $\begin{array}{l}\text { Distribution of workers according to their } \\
\text { qualifications }\end{array}$ & $28(70 \%)$ & 0.022 \\
\hline Maintenance service & $16(42.1 \%)$ & 0.018 \\
\hline \multicolumn{1}{|c|}{$\mathbf{X}^{2}$} \\
\hline \multicolumn{1}{|c|}{ Strategy for attracting new markets } & Respondents & $\mathbf{p}$ \\
\cline { 2 - 3 } $\begin{array}{l}\text { Realization of a new product according to } \\
\text { specifications and documentation from the buyer }\end{array}$ & $22(40.7 \%)$ & 0.001 \\
\hline
\end{tabular}

\section{Result Discussion}

Generally speaking, the respondents are interested in new technologies and realization of new technological solutions. On the other hand, the respondents think the employees are not experienced enough and that they are not distributed properly.

All employees are familiar with the work order (its issue), and the requisition and receipt of materials, tools and equipment. The process of small-scale manufacture begins with issuing a work order and the delivery of accompanying documents. Input and output documents are received if needed, they are poorly controlled, and this is a major problem in SP.

The model enables the reorganization of the work places from an open into a closed type. The distribution of the work space in the MIMP-SPE model must be properly done so as to minimize loss of time due to internal transport.

The organizational measures used in the MIMP-SPE model in the field of the protection of the work force are aimed at enforcing regulations and fighting for the full protection of workers. Managers ensure that the working environment and work assets do not endanger the safety and health of their employees.

The research results point out that SEs do not have appropriate maintenance services. Preventive maintenance in SP includes: regular inspections and the replacement of worn-out or damaged parts.Energy in the small-scale manufacturing process is used: in technological processes; for internal transport and warehouses; for lighting, heating and ventilation, as well as for cooling and air conditioning.

The results show that employees apply the work order, i.e. they submit it along with the items made at the end of the manufacturing process. However, 
Vorkapić M. et al.: The model for improving the manufacturing process in Serbian...

other output documents are submitted during the incomplete process. Waste and scrap are common at the exit, and this occurs due to non-compliance with prescribed procedures or due to the fact that certain methods of work are not standardized.Based on the analysis it can be seen that workers are not assigned defined jobs/tasks, which leads to big losses in the engagement of employees and abandoned jobs/tasks.

Managing the manufacturing process in SEs in Serbia includes: management focus on the optimization and reduction of input value costs, managing manufacturing and non-manufacturing time in the production cycle and constant monitoring and control of external and internal factors.

Control after every operation is performed only when required, which is not good and needs to be improved. The control of tools and measuring instruments is performed. The results show the importance of training workers at the work place and in educational centers.

On the grounds of data processing it is concluded that the key strategy for small enterprises in Serbia is pull strategy or competitive strategy.Although only a small percentage of respondents heard about recoverable manufacturing process, the model certainly provides the space for 4RS model realization with the aim of enterprise's sustainable development. A combination of the aforementioned concepts and the introduction of environmental protection in MIMP - SME model confirms the thesis established by Ward, Bickford and Leong (1996).

\section{Conclusions}

From a theoretical standpoint, the research begins with a basic manufacturing process model (ideal), and develops through the analysis of parameters when a new SP model is introduced. The model provides guidelines as to how external and internal factors influence the quality of small-scale type production processes and offers possibilities to optimize development processes and new product launch. There are some similarities in the economic situation of the countries of the Western Balkans, so the model shows some possibilities for its application on the regional level.

Figure 2 provides guidelines which should improve the process of SP in Serbia, i.e. there is a link with the model (Figure 1). Elements to improve SP are given on the basis of previously defined and analysed sub-processes of production.

In the production planning process, SEs should invest more in product design and new technologies. SE managers also need to reduce employees' 
Vorkapić M. et al.: The model for improving the manufacturing process in Serbian...

activities to the minimum, to deploy the workforce according to the degree of qualifications and to more invest in staff training.

Figure 2 The elements for improving SPEs in Serbia

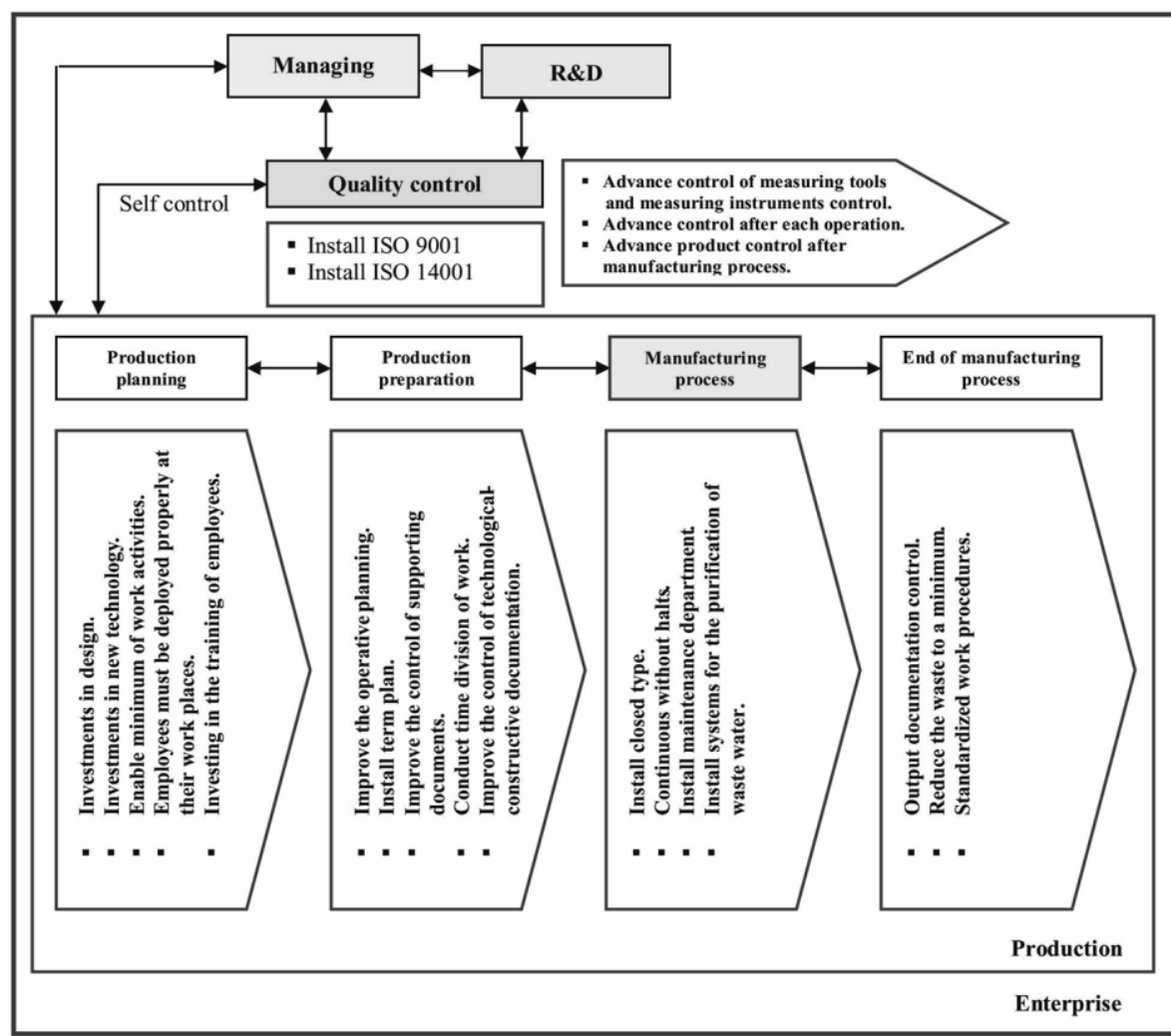

- Install recoverable manufacturing process

- install environmental protection elements according to EUdirectives

ENVIRONMENT

Production preparation must include operational planning and a timeline. It is very important to introduce the issue and control of incoming documents: technological-constructive documentation, acquisition and reverse of tools and materials. Standards on working time must be introduced in order to properly determine employee performance. 
Vorkapić M. et al.: The model for improving the manufacturing process in Serbian...

The manufacturing process in SP involves the introduction of a closed type of workplace because it provides quality production preparation. On the basis of this recommendation, internal transport should be continuous and uninterrupted. A maintenance service is also recommended because potential problems are registered through preventive actions based on situation analysis (technical diagnostics), so the enterprise can intervene and prevent the occurrence of cancelation.

The completion of the production process in SEs should include monitoring of the production from the input of materials to the output of the finished pieces. In this regard, a control of output documents, reducing waste and scrap to a minimum and complete standardization of working procedures are very important for improvement of the manufacturing process. The analysis of manufacturing and non-manufacturing time clearly shows that all capacities are not properly used. During work time, employees often leave the work place for private affairs, due to non-existence of adequate working conditions. This confirms the weakness of open working positions.

Improving the elements of the production process leads to the rationalization of business activities and big savings in materials and energy. This model should reduce output losses to the basic minimum. The improvement of the process involves the continuous control of all parameters after each operation, control of finished pieces after the manufacturing process, as well as the control of environmental protection.

Quality control in the MIMP-SPE model suggests improvement of control: measuring tools and measuring instruments; all operations in the manufacturing process; the finished product after the manufacturing process. The model opens up possibilities for the application of standardized management systems, such as ISO 9001 and ISO 140001 etc., i.e. integration into a unique management system.

The environment dictates the rules to which SEs must react and adapt. Strategies gain in importance through the introduction of the 4Rs model. It should gain appropriate implementation by the use of elements of environmental protection which are in accordance with EU directives.

The work on the model revealed certain irregularities: very poor response from managers/experts and enterprises which could endanger the model and its significance in terms of representative quality, limitations in a geographical sense since the research was conducted in Serbia without Kosovo and Metohia, and apart from statistical verification of influential factors. There is a lack of mathematical modeling as well.

Further work on this model could serve as a special theme for future research through: expansion of the research outside the Republic of Serbia and 
Vorkapić M. et al.: The model for improving the manufacturing process in Serbian...

creation of a mathematical model to verify the elements and connections within the model.

\section{References}

The 4Rs - reduction, reuse, recycling and recovery. (2013) Retrieved 19.10.2014, 2014, from https://www.iisd.org/business/tools/bt_4r.aspx

Abrahamson, S., Wallace, D., Senin, N., \& Sferro, P. (2000). Integrated design in a service marketplace. Computer-Aided Design, 32(2), 97-107. doi: 10.1016/S0010-4485(99)00093-7

Ali, A., Krapfel, R. J., \& LaBahn, D. (1995). Product innovativeness and entry strategy: Impact on cycle time and break-even time. Journal of Product Innovation Management, 12(2), 54-69. doi: 10.1016/0737-6782(94)00027-D

Anderson, C. L. (1987). The production process: Inputs and wastes. Journal of Environmental Economics and Management, 14(1), 1-12. doi: 10.1016/00950696(87)90001-5

Arocena, P., \& Núñez, I. (2010). An empirical analysis of the effectiveness of occupational health and safety management systems in SMEs. International Small Business Journal, 28(4), 398-419. doi: 10.1177/0266242610363521

Ayres, R. U. (1997). Metals recycling: economic and environmental implications. Resources, Conservation and Recycling, 21(3), 145-173. doi: 10.1016/S09213449(97)00033-5

Bohlander, G. W., \& Snell, S. (2010). Managing Human Resources. Mason, OH: Cengage Learning.

Borland, N., \& Wallace, D. (1999). Environmentally Conscious Product Design: A Collaborative Internet-based Modeling Approach. Journal of Industrial Ecology, 3(2-3), 33-46. doi: 10.1162/108819899569539

Bošković, G. The necessitty of the export-oriented reindustrialization strategy of Serbia, // Economic, 49, 2(2011), pp. 233-247.

Buffa, E. S. (1983). Modern Production/Operations Management. New York: Wiley.

Cagno, E., Micheli, G. J. L., Jacinto, C., \& Masi, D. (2014). An interpretive model of occupational safety performance for Small - and Medium-sized Enterprises. International Journal of Industrial Ergonomics, 44(1), 60-74. doi: 10.1016/j.ergon.2013.08.005

Camuffo, A., Gerli, F., \& Gubitta, P. (2012). Competencies matter: Modeling effective entrepreneurship in northeast of Italy small firms. Cross Cultural Management: An International Journal, 19(1), 48-66. doi: 10.1108/13527601211195628

Čala, I., Klarin, M., \& Radojčić, M. (2011). Development of a Stohastic model for determing the elements of production cycle time and their optimization for serial production in Metal processing industry and recycling processes. Journal of Engineering Management and Competitiveness (JEMC), 1(1-2), 21-25.

Desai, D. A. (2008). Cost of quality in small- and medium-sized enterprises: case of an Indian engineering company. Production Planning \& Control: The Management of Operations 19(1), 25-34. doi: 10.1080/09537280701773336 
Vorkapić M. et al.: The model for improving the manufacturing process in Serbian...

Djordjevic, D., Cockalo, D., Sajfert, Z., Bogetic, S., Klarin, M.. Competitive abilities and students entrepreneurial behaviour: The research results from Serbia. // African Journal of Business Management, 5, 26(2011), pp. 10878-10884.

Esteve-Pérez, S., \& Rodríguez, D. (2013). The dynamics of exports and R\&D in SMEs. Small Business Economics, 41(1), 219-240. doi: 10.1007/s11187-012-9421-4

Griffin, A. (1997). Modeling and measuring product development cycle time across industries. Journal of Engineering and Technology Management, 14(1), 1-24. doi: 10.1016/S0923-4748(97)00004-0

Hallberg, K. (2000). A market-oriented strategy for small and medium scale enterprises, Discussion Paper No. 40. Washington, D.C.: World Bank Publications.

Handfield, R. B., Ragatz, G. L., Peterson, K., Monczka, R. M. Involving suppliers in new product development?. // California management review, vol. 42, (1999), pp. 59-82.

Hauschild, M. Z., Jeswiet, J., \& Alting, L. (2004). Design for Environment - Do We Get the Focus Right? CIRP Annals - Manufacturing Technology, 53(1), 1-4. doi: 10.1016/S0007-8506(07)60631-3

Jeffrey, K. R., \& Hunt, D. (1985). Design in small manufacturing companies in Scotland. Design Studies, 6(1), 18-24. doi: 10.1016/0142-694X(85)90037-7

Kerr, A., \& McDougall, M. (1999). The small business of developing people. International Small Business Journal, 17(2), 65-74. doi: 10.1177/0266242699172004

Klarin, M., Spasojević Brkić, V., Stanisavljev, S., Sajfert, Z., Radojičić, M., Nikolić, M., \& Jovanovski, B. (2012). A Stochastic Model to Determine the Elements of Production Cycle Time in Enterprise. Journal of Engineering Management and Competitiveness (JEMC), 2(2), 48-56.

Konstantaras, I., \& Skouri, K. (2010). Lot sizing for a single product recovery system with variable setup numbers. European Journal of Operational Research, 203(2), 326-335. doi: 10.1016/j.ejor.2009.07.018

Lindner, A., Bagherzadeh, M. SME Statistics: towards more systematic statistical measurement of SME behavior. // Expert Group Meeting on Industrial Statistics. / Two United Nations Plaza, 2005

Mallidi, K., Paraskevopoulos, A. T., \& Paganelli, P. (1999). Process modelling in small-medium enterprise networks. Computers in Industry, 38(2), 149-158. doi: 10.1016/S0166-3615(98)00115-8

Maxwell, D., \& van der Vorst, R. (2003). Developing sustainable products and services. Journal of Cleaner Production, 11(8), 883-895. doi: 10.1016/S09596526(02)00164-6

Milovanović, G. (2005). Small and Medium Enterprises as a Base for Restructuring Serbian Economy [in Serbian]. Facta universitatis - series: Economics and Organization, 2(3), 201-208.

Petersen, K. J., Handfield, R. B., Ragatz, G. L. A Model of Supplier Integration into New Product Development. //. Journal of Product Innovation Management, 20, 4(2003)., pp. 284-299.

Roper, S. (1998). Entrepreneurial Characteristics, Strategic Choice and Small Business Performance. Small Business Economics, 11(1), 11-24. doi: 10.1023/A:1007955504485 
Vorkapić M. et al.: The model for improving the manufacturing process in Serbian...

Sandee, H., \& Rietveld, P. (2001). Upgrading Traditional Technologies in Small-Scale Industry Clusters: Collaboration and Innovation Adoption in Indonesia. The Journal of Development Studies, 37(4), 150-172. doi: $10.1080 / 00220380412331322081$

Sarkis, J. (2003). A strategic decision framework for green supply chain management. Journal of Cleaner Production, 11(4), 397-409. doi: 10.1016/S09596526(02)00062-8

Subrahmanya, M. H. B. (2005). Small-scale industries in India in the globalisation era: performance and prospects. International Journal of Management and Enterprise Development, 2(1), 122-139.

Tapio Lindman, M.. Open or closed strategy in developing new products? A case study of industrial NPD in SMEs. // European Journal of Innovation Management, 5, 4(2002), pp. 224-236.

Urošević, S., Stamatović M. Role of Small and Medium-Sized Enterprises in the Enhancement of the Serbian Textile Industry in Times of Crisis. // Fibres \& Textiles in Eastern Europe, 19, 4(2011), pp. 87.

Ward, P. T., Bickford, D. J., \& Leong, G. K. (1996). Configurations of Manufacturing Strategy, Business Strategy, Environment and Structure. Journal of Management, 22(4), 597-626. doi: 10.1177/014920639602200404

Westkàmper, E., Feldmann, K., Reinhart, G., \& Seliger, G. (1999). Integrated Development of Assembly and Disassembly. CIRP Annals - Manufacturing Technology, 48(2), 557-565. doi: 10.1016/S0007-8506(07)63234-X 